\title{
"DO YOU NEED TO KNOW THE PERSON TO DONATE?" FACEWORK STRATEGIES IN BRAZILIAN BLOOD DONATION CAMPAIGNS: A MULTIMODAL ANALYSIS
}

\author{
Luzia Schalkoski Dias* \\ Angela Mari Gusso* \\ Pontifícia Universidade Católica do Paraná \\ Escola de Educação e Humanidades \\ Curso de Letras
}

\begin{abstract}
The study intends to point out the analytic potential which the interrelation between the Politeness Theory (BROWN; LEVINSON, 1987) and the semiotic approach of the Grammar of Visual Design (KRESS; VAN LEEUWEN, 2006) can provide to the analysis of politeness strategies used in the advertising of public communication. We carried out a qualitative analysis of two advertising pieces in blood donation campaigns conducted by the Brazilian Ministry of Health. The textual genres analyzed, a poster and a folder, are characterized by their semiotic multimodality; therefore, resources are used together to produce social meanings in tune with the interests and motivations of the producers. It was highlighted by the data analysis that, as the positive politeness strategies are used by the advertisers to try to get close to the addressees, the visual language is also handled according to certain standards, in order to capture the attention of the targeted public. The corpus suggests that the visual structures reinforce the verbal strategies used to intensify the atmosphere of closeness between those involved in the interaction situation.
\end{abstract}

Keywords: Multimodality. Politeness strategy. Advertising. Blood donation.

1 INTRODUCTION

The technological advances in the production of written and visual communication during the last decade have had significant impact in the forms of social communicative interaction, expanding the ways of producing and broadcasting information in contemporary society.

Thus, as argued by Dias and Gusso (2015), people have been required to have new reading and writing abilities in connection with the new technologies. No longer is the mastery of reading printed texts enough, as people now need to interact with a number of multimodal texts conveyed by printed, analogic and digital media.

\footnotetext{
* Associate Professor of Portuguese and Linguistics at the Pontifical Catholic University of Paraná, PUCPR, Brazil. PhD in Linguistics, Pragmatics, at Federal University of Paraná, UFPR, Brazil. Member of Language and Culture Research Group (UFPR/CNPq).E-mail: luzia.schal@gmail.com

** Associate Professor of Portuguese and Linguistics at the Pontifical Catholic University of Paraná, PUCPR, Brazil. PhD in Linguistics at Federal University of Paraná, UFPR, Brazil. E-mail: amgusso@terra.com.br
}

DIAS, Luzia Schalkoski; GUSSO, Angela Mari. “Do you need to know the person to donate?” Facework strategies in Brazilian blood donation campaigns: a multimodal analysis. Linguagem em (Dis)curso - LemD, Tubarão, SC, v. 16, n. 3, p. 401-419, set./dez. 2016. 
Marcuschi (2005, p. 19) highlights that the textual genres are narrowly connected to social practices, cognitive aspects, interests, power relations, technologies, discursive activities and culture. This transformation can be observed in the texts produced in the discursive field of advertising, object of this study.

Often, different advertising genres have attracted the attention of researchers (ESCRIBAÑO, 2006; DEL SAZ-RUBIO, 2000, 2011; PALACIOS; SENA, 2010; PISHGHADAM; NAVARI, 2012, among others) that have studied pragmatic-discursive aspects, including those regarding linguistic politeness. However, traditionally, such studies have emphasized verbal texts, with little regard to non-verbal elements that are often the hallmark of such genres. In this respect, the work of Pennock-Speck and del Saz-Rubio (2013) is almost an exception.

With regard to studies of politeness, the fact that gestures can also work as indicators of (im)politeness in some cultures shows the necessity for studies in this area to go beyond verbal (im)politeness in discourse. Other than that, multimodal genres, such as advertising, generally have a variety of non-verbal elements that are interrelated with the verbal message; therefore, their consideration can enrich the study of linguistic politeness. In this sense, it has been argued that "The concepts that have been used to describe the structure of language as a resource and the 'footing' of talk can also be applied multimodally" (VAN LEEUWEN, 2004, p. 18).

In order to widen the scope of the analysis beyond the verbal dimension, we propose to combine the theoretical framework of Brown and Levinson's politeness model (1987) and the semiotic approach of Grammar of Visual Design, by Kress and van Leewen (2006), with the objective of analyzing two advertising pieces of blood donation advertised by the Brazilian Ministry of Health. We do not disregard the discretions about some aspects with reference to Brown and Levinson's (henceforth B\&L) model of politeness, such as the consideration that its strategic and instrumental view of verbal interaction could be less than realistic when applied in everyday communication (EELEN, 2001) or the questioning of the universality of politeness strategies (MATSUMOTO, 1988; IDE, 1989). However, as it is claimed by Pennock-Speck and del Saz-Rubio (2013, p. 39), in the context of advertising "most of the objections which have been raised regarding the B\&L approach either do not apply or can actually be construed as advantages". Therefore, we adhere to the argument of these authors that "even though B\&L's strategic and instrumental view of verbal interaction may be unrealistic when it comes to ordinary conversation (...), it seems ideally suited to the premeditated discourse found in advertising copy".

Keeping in mind these considerations, our main purpose in this article is to point out the analytic potential that the interrelation between Politeness Theory and the Grammar of Visual Design can provide to the analysis of face management strategies utilized in advertising pieces from campaigns of Brazilian blood donation. Therefore, this work analyses how verbal and non-verbal resources are articulated to project, preserve, or reinforce the faces of the advertiser and the targeted public.

In section 2, we introduce the main theoretical notions that form the basis of our analysis. In section 3, we describe the corpus and explain the methodology used. In section 4 , we develop the analysis of the data and results. In section 5 we present our conclusions. 

2.1 BROWN AND LENVINSON'S POLITENESS THEORY AND THE ADVERTISING DISCOURSE

The studies on linguistic politeness gained notoriety in the field of pragmatics from B\&L's theoretic formulations. They observed that most speech acts produced in everyday conversations do not happen as efficiently as suggested by the Gricean Maxims. Thus, they suppose that the concern in giving some attention to two basic desires of human beings - the desire of being appreciated by others, and the desire of not having one's actions prevented by others - would be a strong motive for speakers of different languages not to follow such maxims. In this perspective, politeness would explain the deviation of rational efficiency in the interactions, being expressed precisely by this deviation (B\&L, 1987, p. 4). This communication model conceives linguistic politeness as a phenomenon centered in the metaphorical notion of face, initially elaborated by Goffman (1967). This notion of face, according to B\&L (p. 62), has two sides: the negative and the positive faces. The negative face is seen as the desire of any person neither having his/her actions prevented nor suffering impositions, which means having their territory respected by others. The positive face refers to the human desire of being accepted by others, and of having their desires shared by at least some people. Thus, these authors propose that the linguistic politeness strategies used by speakers are directed to the safeguarding of these faces of the interlocutors. In this sense, such verbal procedures have been considered facework strategies.

B\&L (1987) classify some acts (both verbal and non-verbal) as intrinsically threatening to the negative and/or positive face of both the speaker $(\mathrm{S})$ and the hearer $(\mathrm{H})$, or the advertiser and the reader in the case of advertising pieces. Such Face Threatening Acts (FTAs) call for redressive action in the form of politeness strategies (B\&L, 1987, p. 24). This model proposes that at the very moment of social interaction, speakers rationally assess the seriousness of the FTA on the basis of three independent and culturally determined variables - the social distance (D) and social power (P) existing between $\mathrm{S}$ and $\mathrm{H}$, and the ranking of imposition $(\mathrm{R})$ of the act itself. Any rational $\mathrm{S}$ will thus seek either to avoid any FTAs in his or her interactions with $\mathrm{H}$, or to employ some strategies to minimize the threat that may arise during these interactions. B\&L present five hierarchically ordered strategies depending on the amount of facework required: first, $\mathrm{S}$ must decide whether to carry out the FTA or not. If she or he decides to go ahead, then the FTA can be done on record or off-record. If the FTA is done on record, it can be performed without redressive action, or baldly (Donate your blood!). On-record FTAs with redressive action can take two forms depending on the aspect of face being emphasized: negative (Would you please donate your blood?) or positive (Donate your blood, buddy).

Positive politeness strategies (PPS), as approach-based strategies, include the compliments, the seeking of agreement, joking, claiming reflexivity of goals, claiming reciprocity, and uttering expressions of sympathy and cooperation. Negative politeness strategies (NPS) aim at the avoidance of imposing upon the addressee through mitigating devices. Off-record politeness strategies (ORPS) help speakers indirectly con $\neg$ vey certain assumptions and thus avoid the potential responsibility that might be resultant from using more direct strategies. Table 1 presents the main strategies found in our data. 
Table 1 - Politeness Strategies identified in the analyzed data

\begin{tabular}{|c|c|}
\hline Main Positive Politeness Strategies: & Positive Politeness Sub-strategies (PPS) \\
\hline \multirow[t]{3}{*}{ a. Claim common ground } & PPS2 Exaggerate \\
\hline & PPS4 Use in-group identity markers \\
\hline & PPS7 Presuppose, assert, raise common ground \\
\hline \multirow[t]{2}{*}{ b. Convey that $S$ and $H$ are co-operators } & PPS11 Be optimistic \\
\hline & PPS13 Give or ask for reasons \\
\hline Main Off-record Strategies: & Off-Record Politeness Sub-strategies (ORPS) \\
\hline \multirow{4}{*}{$\begin{array}{l}\text { a. Invite conversational implicature, via hints } \\
\text { triggered by violation of Gricean Maxims }\end{array}$} & ORPS2 Give association clues \\
\hline & ORPS5 Overstate \\
\hline & ORPS9 Use metaphors \\
\hline & ORPS10 Use rhetorical questions \\
\hline \multirow[t]{2}{*}{ b. Be vague or ambiguous } & ORPS11 Be ambiguous \\
\hline & ORPS15 Be incomplete, use ellipsis \\
\hline Main Negative Politeness Strategy: & Negative Politeness Sub-strategy (NPS) \\
\hline a. Communicate S's want not to impinge on $\mathrm{H}$ & NPS7 Impersonalize S and H: Avoid the pronouns 'I' and 'you' \\
\hline
\end{tabular}

When referring to the discursive activity of advertising, Palacios and Sena (2010) note that one of the main points of anchorage between the concept of face, the concept of politeness, and advertising discourse settings is the premise that, during the construction process of the utterance, the advertisers are always aware of the referential universe of the target group. According to del Saz Rubio (2000, p. 43), in mediated interaction, in which the discursive activity of advertising is inserted, the need to avoid confrontation and make the interlocutor feel comfortable and involved is apparent. In that sense, the function of positive politeness in advertising discourse has a dual nature, as "it is a mechanism at the service of emphasis" while trying to mitigate its own illocutionary force.

In the advertising context in general, politeness not only provides the attenuation of threats to the faces, but also seeks to exalt the advertised product, either by association with certain well-regarded environments or by the construction of a markedly positive face of the consumer (ESCRIBAÑO, 2006). In the case of blood donation campaigns, the object of analysis in this article, as there is no product to be consumed, we consider that what is sought is the exaltation of the act of voluntarily donating blood itself and, consequently, there is a tendency to emphasize the positive face of likely donors. Thus, on the use of language in this context, politeness acquires a key role in the construction of utterances. 


\subsection{SEMIOTIC APPROACH OF THE GRAMMAR OF VISUAL DESIGN}

With the purpose of identifying the regularities of visual structures in the western world, Kress and van Leeuwen (2006) have proposed a new way of analyzing images from the assumption that their elements combine syntagmatically, as happens with verbal resources. The tool developed by them - The Grammar of Visual Design - provides parameters to investigate how the elements of a multimodal representation combine to form a coherent whole. The proposal is supported by the perspective of Social Semiotics, according to which the language is conceived as part of the social and cultural context and needs to be analyzed in conjunction with other modes of representation involved in the text production. In this sense, verbal language is always built by multiple modes; the very physical space where the written texts are conveyed is a way of meaning (SCOLLON; LEVINE, 2004).

Here, we give a brief discussion of the Grammar of Visual Design - GVD (KRESS; VAN LEEUWEN, 2006), as its categories will be used in this study with the objective of uncovering discursive opacities, the underlying intentions of the texts that combine verbal signs with imagery, since, according to del Saz Rubio (2011), the images appeal to a more emotional than analytical part of the addressee.

Adapting the metafunctions (ideational, interactional and thematic) of verbal language, postulated by the Systemic Functional Linguistics (HALLIDAY, 1994) for the analysis of the visual semiotic mode, Kress and van Leeuwen (2006) propose that for creating meanings, three articulated semiotic functions must be considered (representational, interactive and compositional), which we will summarize next, since such categories will be at the basis of our analysis.

The representational function focuses in several relationships among the represented participants (RPs), which can be people, objects, places, geometrical forms, etc. In terms of representing world experiences, the images can take the form of a narrative structure - an action unfolds visually, indicated by a vector that links the elements of the composition - or a conceptual structure - the actor is not involved in any activity, and there are (consequently) no vectors; the participant is then represented by his/her structure or meaning.

Regarding the interactive function, it is considered that the understanding of interactive meanings is related to the way they are performed on the images. Kress and van Leeuwen (2006) identify a number of factors responsible for establishing such meanings:

a) contact - in the offer image, there is no direct eye contact between the interactive participant (IP) ${ }^{1}$ and represented participant (RP), and the RPs are exposed as objects of contemplation; in the demand image, the RP challenges the viewer in the sense that it (the demand image) expresses a contact, even if imaginary;

1 This term refers to the image reader or viewer.

DIAS, Luzia Schalkoski; GUSSO, Angela Mari. “Do you need to know the person to donate?” Facework strategies in Brazilian blood donation campaigns: a multimodal analysis. Linguagem em (Dis)curso - LemD, Tubarão, SC, v. 16, n. 3, p. 401-419, set./dez. 2016. 
b) social distance (framing) - the participants can be represented as closer to the observer or as more distant, according to the degree of the plane opening used by the producer of the image;

c) attitude (angle/perspective) - pictures taken in frontal or oblique angles suggest, respectively, involvement and detachment of the producer of the image. The power relations between RP and IP are coded according to how "vertical" the angle is. Thus, RPs photographed with low angle hold the power, but if focused with high angle, it is the advertiser and the observer of the image who will exercise the power. In those cases in which the image is at eye-level the power relation is symmetrical among the participants.

In the interactional level, Kress and van Leeuwen note the issue of the messages' reliability and state that "the realization of modality in images is much more complex and finely graded than the realization of modality in language" (2006, p. 163), as the latter is achieved by means of linguistic resources such as modal verbs or adjectives that express valuation. An image may appear more or less real according to certain modality cues that it gives. The parameters of modality identified by the authors relate to saturation, differentiation and modulation of colors, lack of background or background thoroughly detailed, representation on a scale that goes from obscuring to reproducing details, lack of depth or its maximum reproduction, lighting, and brightness.

The compositional function, in turn, refers to how the representational and interactive elements join to form a meaningful whole. The integration between the compositional elements ensures the construction of the textuality. This condition is linked to the relation of elements with the world they represent and where they are inserted, of the elements among themselves, and with the reader as well. Three systems are responsible for integrating these meanings of the compositions:

a) information value - although the arrangement of visual elements in the text probably is unconscious, there is an association of regular meanings to parts of the visual space: i) the elements placed to the left are the Given - something the readers presumably already know; the messaged supposed as New, usually is positioned to the right; ii) the upper part of the space, named Ideal, is reserved to what is emotional and object of desire - destined to the essence of information; the lower half is reserved to the Real element, which represents more concrete information, taken as true; iii) a participant is in the center when is considered to be "core information", so that other elements must be understood in relation to it;

b) salience - this system integrates the RPs giving them different degrees of prominence, as a result of interrelated factors, such as size, contrast of tones and colors, and image resolution;

c) framing - the presence of dividing lines, discontinuity of color and contour, and spaces among the elements are some strategies employed to indicate that the participants of the composition must be considered separately. On the other hand, the absence of typographic features for separation and the use of same colors and shapes in more than one element suggest the possibility of establishing a connection between them. 
Although a brief presentation of visual grammar was made here, it is possible to glimpse its potential in the sense of providing subsidies for a more critical analysis of the imagery, considering a particular form of conveyance and reception that characterizes them in social systems.

\subsection{ADVERTISING GENRES CHARACTERIZATION: POSTER AND FOLDER}

The poster and the folder are multimodal genres widely used by advertising professionals with the purpose of, among other things, conveying advertising campaigns; these are dynamic texts of broad social circulation in various media, printed or digital. In these textual genres, image and word are closely related and "all resources used in the construction of textual genres have a rhetorical function in the construction of the meanings of texts" (DIONÍSIO, 2005, p. 159). To characterize these genres, the linguistic and textual, social and pragmatic dimensions will be considered, since, as argued by Marcuschi (2005), the methodology for textual analysis cannot take into account only the form, but also the functionality and the compositional structure because it is a complex phenomenon involving multiple aspects: linguistic, discursive, historical, and pragmatic, among others.

The advertising poster emerged in the nineteenth century closely related to art, initially with the purpose of announcing commercial and industrial products, but came to be used in the dissemination of cultural, social and political issues (RABAÇA; BARBOSA, 1995). It constitutes one of the most frequent means of publicity, being an economic and easy way of either just divulging information or also appealing for involvement or participation, as is the case of the posters in the blood donation campaigns. It is an ephemeral medium, usually produced in large paper sizes so that different people can read it simultaneously. For this reason, it is often displayed in places that people walk by. It is characterized by containing a striking verbal message of quick reading; therefore, its content needs to be clear and suggestive; in this sense, style, size and color of the letters are also given special attention. The image, in turn, is large with colors related to the theme that contrasts with the background of the poster intending to create a highly appealing effect.

As with the poster, the word folder designates both the textual genre and its medium. This genre appeared in the media and advertising industry as a device for marketing and advertising professionals with the objective, among others, to serve for the execution of advertising campaigns (KARWOSKI, 2005). This type of advertisement circulates in printed-paper with, at least, one fold and illustrations; the cover features the main appeal; inside there is a detailing of what was advertised, and the last page usually contains the means of contact with the advertiser. The amount of information conveyed in the genre is relatively large; therefore, a reasonable place and some amount of time are necessary to read it. In folders, verbal and non-verbal signs are merged. However, the latter gain predominance and special emphasis on compositional structure. More specifically, the folders of health services are characterized by the presence of persuasive imagery and verbal resources, quantitative data, and guidelines on health and quality of life. The text formatting and the layout of verbal language associated to the image are forms to express the content, directing the reader to the construction of the meaning. 


\section{CORPUS OF RESEARCH AND METHODOLOGY}

The blood donation campaigns promoted by the Brazilian Ministry of Health $(\mathrm{BMH})$ in the last few years are in agreement with the World Health Organization's (WHO) objective that all countries obtain all their blood supplies from voluntary unpaid donors by 2020. Although the need for blood is universal, there is a marked difference in the level of access to safe blood between high- and low-income countries (WHO, 2014. p. 1).

We analyzed a poster and a folder from two blood donation campaigns promoted by the BMH between 2013 and 2014. These campaigns are embedded in a sort of communication that has been denominated public communication (ZÉMOR, 2005; BRANDÃO, 2009; KOÇOUSKI, 2013) or, more specifically, public health communication (BERNHARDT, 2004). Here we will use the concept of public communication campaigns as purposive attempts to inform or influence behaviors in large audiences within a specified time period by means of an organized set of communication activities and featuring an array of mediated messages in various channels usually to produce noncommercial benefits to individuals and society (RICE; ATKIN, 2009; ATKIN; RICE, 2013).

In June 2013, the BMH released the campaign No matter who it's for, be a donor (Seja para quem for, seja doador). It was directed towards young people between the ages of 16 and 29, seeking to reinforce the idea that it is not necessary to be close to someone who needs blood to raise awareness to the cause, and therefore, it presented examples of participation of people involved in real cases (PORTAL PLANALTO, 2013; BRASIL, 2014). From this campaign, a poster will be analyzed. In 2014, the same slogan was maintained to reinforce that concept and a new set of advertising pieces was released. The folder analyzed belongs to this last campaign. The criteria used to choose both campaigns was the fact that they have higher amounts of advertising materials, as well as greater diversity of genres, since the intention is to investigate the politeness strategies in diverse genres.

In an attempt to achieve the objectives proposed in this article (cf. section 1), a qualitative analysis of the selected advertisements will be developed in the next section. Aiming to ensure greater clarity in identifying the contribution of each theoretical approach, GVD and politeness theory, the pieces were analyzed in two stages: first, the non-verbal aspects are discussed and, in a different subsection, the verbal aspects are taken into account.

Regarding non-verbal aspects, the advertisement pieces were analyzed taking into account the relationship amidst the three semiotic functions proposed by Kress and van Leeuwen (2006), presented in 2.2. In turn, the analyses of the verbal aspects are grounded on the postulates of Brown and Levinson (1987) on politeness strategies. 
4 ANALYSIS AND RESULTS FROM A MULTIMODAL APPROACH 4.1 ANALYSIS OF THE POSTER

In order to respect the chronological sequence of release of each blood donation campaign, we started with the analysis of the poster, which was aired in 2013.

Figure 1 - Poster of blood donation campaign, 2013

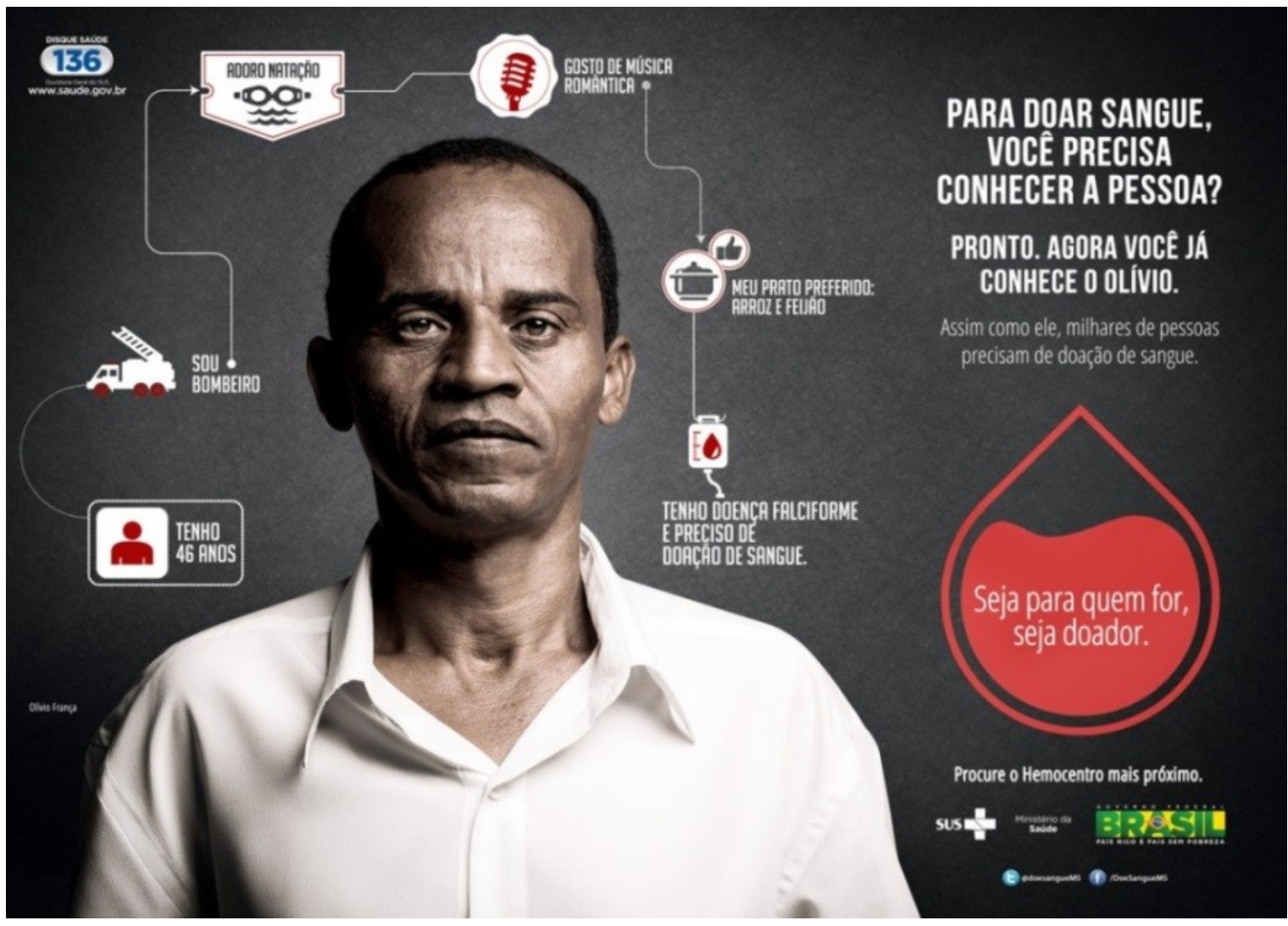

Source: https://fenafal.files.wordpress.com/2013/06/cartaz_olivio_foto_nova.jpg

\subsubsection{NON-VERBAL ASPECTS}

In the poster (figure 1), verbal and non-verbal elements are not separated by boundary lines, and both participate in the production of meanings. The scene suggests that the RP is going through a difficult health problem and counts on the reader's solidarity. The RP's facial expression, personal data and the utterance "Done: now you know Olívio" join the request marked in the red background, in contrast with the prevailing black and the text elements in white.

Here we have a conceptual structure since in the scene no action takes place, as the RP (Olívio) displays a static behavior. Moreover, there is no vector (a hallmark of narrative structures) in the scene. 
It is from the six constituents of the figure around the human image - called symbolic attributes by GDV - that the reader can assign meanings to the RP. In this case, he is seen as a representative of all Brazilians who need blood donations to survive.

From the perspective of interactive function, this is an image of request, since the RP looks straight into the observer's eyes, establishing contact, even if imaginary. This straight gaze induces the reader to accept the request in a verbal mode, as well: No matter who it's for, be a donor. The producer or author of the advertising piece employs the gaze to touch, by visual appeal, the IP in her/his emotions; moreover, the staring is an invitation to the reader to take part in the visual scene, promoting complicity between RP and IP.

The new information is placed on the upper right, which is conventionally reserved for emotional material, and for objects of desire.

The character gained maximum projection by the use of several strategies: the closed plane and angle of the photograph, the white color of his clothing in contrast with the black background, lighting and brightness on the right side of his face, exactly where the information about his need to receive a blood notation is placed. These strategies have the objective of generating a sensation of trust and empathy on the IP, prompting her/him to engage in the campaign.

The overall funeral tones, together with the countenance of suffering of the RP, transmit a sensation of empathy. The darkness represented by the black background may overwhelm the only bright spot of hope in the face of the main character if the request does not produce the desired result.

\subsubsection{VERBAL ASPECTS}

In this section, we analyze the verbal strategies employed in the poster, which are translated in the following.

\section{Figure 1 - Text - Poster}

1 Tenho 46 anos. Sou bombeiro. Adoro natação. Gosto de música romântica. Meu

2 prato preferido: arroz e feijão. Tenho doença falciforme [PPS13] e preciso de sua doação de sangue.

I am 46 years old. I am a firefighter. I love swimming. I like romantic music. My favorite dish: rice and beans. I have sickle-cell disease and need your blood donation.

3 Para doar sangue, você precisa conhecer a pessoa? [ORPS10]. Pronto, agora você já conhece o Olivio.

Do you need to know the person to donate blood? Well, now you know Olívio.

4 Assim como ele, milhares de pessoas precisam de doação de sangue.

Just like him, thousands of people need a blood donation.

5 Seja para quem for, seja doador. Procure o hemocentro mais próximo. [ORPS15, ORPS2]

No matter whom it is for, be a donor. Look for the nearest blood bank and donate. 
One can say that the fact that utterances 1 and 2 present the discourse of a Brazilian citizen (Olívio) who depends on blood donations, with which many Brazilians will identify themselves, consists of a discursive strategy of positive politeness [PPS7], to the extent that it places the main character close to the reader.

The reader proximity effect elapses, in addition to non-verbal resources used in the composition of the image, from the information that Olívio reveals about himself to get the reader familiar with him - his age, profession, musical and culinary taste - since blood donation is a more common practice among known people.

In utterance 3, on the upper right portion of the poster, the author makes a rhetorical question, that is, a question that leaves its answer implicated (B\&L, 1987, p. 223). This constitutes an off-record politeness strategy [ORPS10], allowing him to perform the FTA and, at the same time, attenuate the imposition on the negative face of the target public. We believe that trough this rhetorical question ("Do you need to know the person to donate blood?"), the advertiser threatens the negative face of potential donors, but in a hidden way, by implying that, since they have already known Olívio, there is no reason not to be sympathetic with the many Olívios that need blood transfusions.

At last, the campaign slogan is introduced on the right bottom, with the use of offrecord strategies [ORPS15, ORPS2], that is, without mentioning the object of the donation, but giving a clue through the use of the expression "blood bank", helping the reader to deduce the information.

\subsection{ANALYSIS OF THE FOLDER}

As mentioned above, a folder is a publicity piece printed on paper with at least one fold, and illustrations. On the cover a folder presents the main message, while in the internal pages the message is detailed. Usually, the advertiser's contact information can be found on the folder's back. Similarly to what happens to the textual genre poster, in a folder there is a mix of verbal and non-verbal elements, with special emphasis given to the latter in the composition of the piece. 


\section{Figure 2 - Folder of the blood donation campaign, 2014}
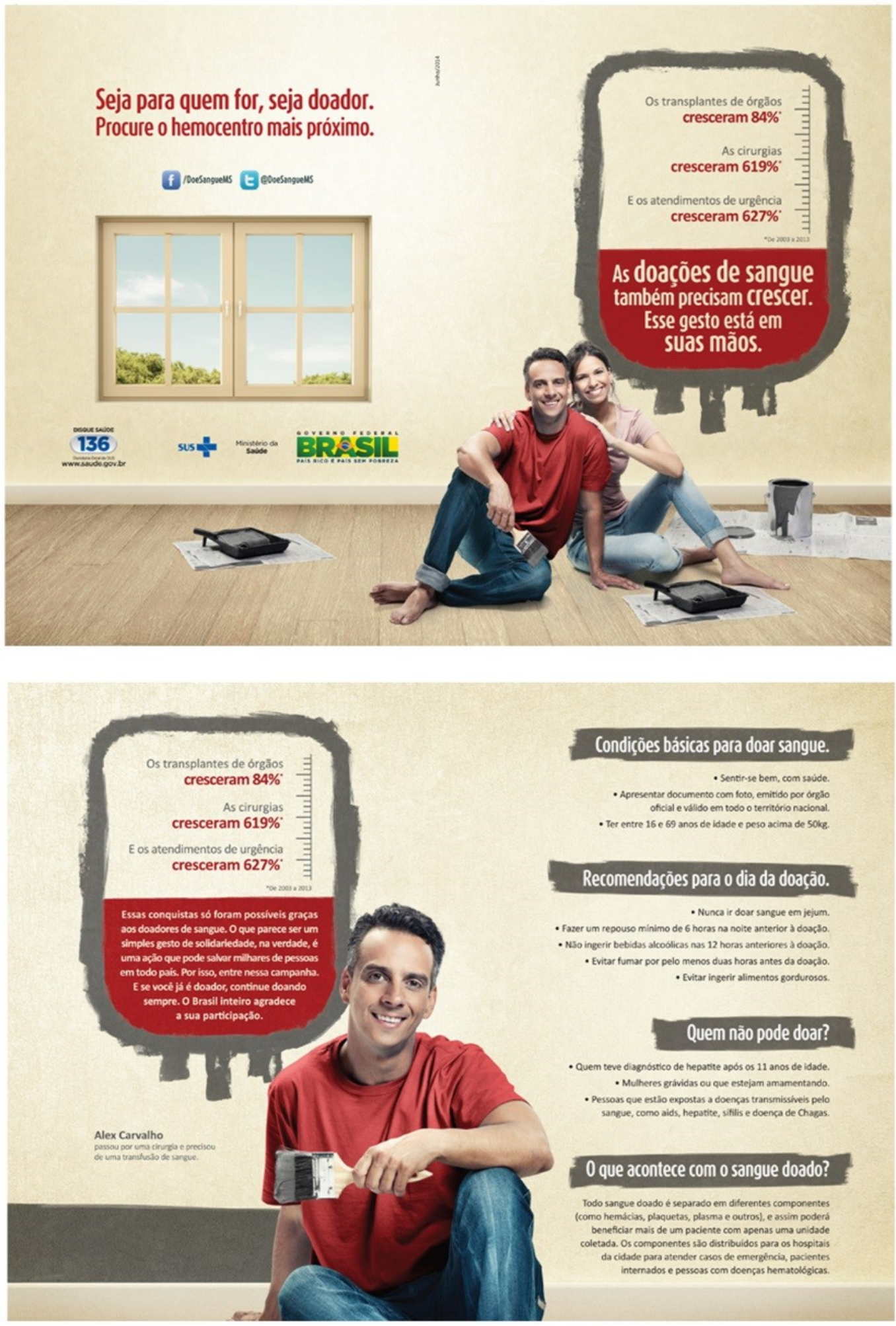

Source: http://portalarquivos.saude.gov.br/campanhas/2014/Doacao_de_Sangue/MS_DOACAO_DE_SANGUE _FOLDER_A5.jpg

DIAS, Luzia Schalkoski; GUSSO, Angela Mari. “Do you need to know the person to donate?” Facework strategies in Brazilian blood donation campaigns: a multimodal analysis. Linguagem em (Dis)curso - LemD, Tubarão, SC, v. 16, n. 3, p. 401-419, set./dez. 2016. 
In putting the folder together, the verbal language along with its typesetting and formatting, in association with the photographs, constitute content-expression forms, and guide the reader towards construction of the meaning. In the folder's front (side 1), the scene suggests a couple restarting life: a house to be dwelled, under reformation, without furniture or curtains. The reader or observer can see, through the window, blue sky and trees, which gives the impression of an agreeable place, in which a healthy and happy life can be lived.

The displayed elements are composing a narrative structure, since an action is unfolding symbolized by a vector linking those elements. In the picture, the vector is the brush with gray paint held by one of the RPs and relates him to the blood bag. It is an image of offer, since there is no direct eye contact among the interactive and the represented participants: the RPs are exposed as objects beheld, and the folder readers do not necessarily feel compelled to manifest a reaction or to take a particular action.

The long-distance photograph places the represented characters and the scene at an equally large social distance from the reader. The fact that the couple was photographed in full body (in open plane) confers an impersonal character between themselves and the reader, prompting the reader to contemplate the scene only.

The red color links the RP to the campaign's slogan and with an appeal for the reader to donate, displayed on the right, inside a bag whose content fills it only to half capacity. On the red background suggesting blood, there is a verbal message whose content calls on the target public to engage in the campaign. The slogan - No matter who it's for, be a donor - has gained emphasis due to the font size used in it. The verbal appeal also combines fonts of different sizes, putting emphasis on the expressions blood donations, grow, and your hands. That information is placed in the right half of the picture, which is the place where usually new information for the reader is put. The gray color of the paint in the can, brush and trays is responsible for linking the blood bag on side 1, the bag placed on side 2 , and the directions given to the readers.

On side 2 of the folder, as on side 1, the verbal and non-verbal elements are amalgamated to produce their meanings. It also presents a narrative structure, since, visually, an action unfolds denoted by a vector linking the elements of the composition: the brush with gray paint in the hands of the main character - he is identified as Alex Carvalho, someone who has received in the past a blood donation - connects the scene to current needs, that is, the current shortages in blood banks. Moreover, it relates the scene to directions on how to donate blood. In this case, we have an image of demand, since the PR (Alex Carvalho) seems to look straight to the observer, thereby creating an engagement, even if imaginary, between them. The impression is that the Actor challenges the reader to establish contact.

The choice of a front angle photograph at the eye-line height (and hence character and reader standing eye-to-eye) give the impression of proximity and equality of power between them. The framing of the character in middle plane puts him at a social distance that gives the observer a sensation of intimacy with the scene and the RP. 
Analyzing the position occupied by the RP's in the composition, one notes that the main character, the kernel of the information, occupies the central place, while the elements on the margin are connected to him. On his left side, there are the pieces of information already given, and therefore a familiar content. On the right, the elements provide the new content, to which most attention must be given.

On the upper part, general information (the ideal) is placed. Opposed to it, the bottom is reserved for the element of reality, that is, the character Alex Carvalho, who did in fact undergo a surgery and needed a blood transfusion. The main character is given emphasis also by his shirt's color, related to the blood bag to his left, and in contrast with the white background: the red color establishes continuity among the elements, which it represents.

The brush, with gray paint, is a vector linking Alex Carvalho to the readers: he is the one giving instructions, because of his own previous experience with the theme.

\subsubsection{VERBAL ASPECTS}

Considering the verbal aspects, the left side on the folder's front contains the main call, which in this genre, has the function of arousing the reader's curiosity and leads him or her to know more about other parts of the text:

Seja para quem for, seja doador [ORPS15]. Procure o hemocentro mais próximo [ORPS2].

No matter who it's for, be a donor. Look for the nearest blood bank.

In our case, the speech act of calling the reader to donate blood, in spite of the buzzwords utilized, is performed off-record. This type of act, according to B\&L (1987), would threaten the negative face of the reader. Based on this idea, the use of off-record politeness strategies allows the speaker to do the FTA without taking responsibility for it. Leaving it to the reader to decide how to interpret the act; in this way, by not making the object of donation explicit, the utterance of the call employs the ORPS15 strategy since, by mentioning the expression "blood bank", it gives the reader a clue so that he or she can fill in the information.

As noted in the previous section when we dealt with the non-verbal aspects that contribute to putting together the meanings of the advertising piece, the supposedly new information to the reader is displayed on the upper right side of the folder:

Os transplantes de órgãos cresceram $84 \%$.

As cirurgias cresceram 619\%.

E os atendimentos de urgência cresceram $627 \%$.

*De 2003 a 2013

As doações de sangue também precisam crescer [NPS7]. Esse gesto está em suas mãos [ORPS11].
Organ transplants have increased $84 \%$.

Surgeries have increased $619 \%$.

Emergency treatments have increased $627 \%$.

*From 2003 to 2013

Blood donations also need to increase.

This action is in your hands.

The statistical data presented function as arguments to reinforce the slogan's call. It is interesting to note the syntactic parallelism obtained by repeating the syntactic structure (nominal phrase + verb to increase + statistical information) when presenting the data. It 
is worth remembering that the repetition of words, structures and ideas, in particular in written discourse, is a powerful rhetorical resource. It produces argumentative effects that go beyond style, and they are used for persuading the reader $(\mathrm{KOCH}$; ELIAS, 2011a; JOHNSTONE, 1987). Therefore, the recurrent appearance of the verb to increase emphasized in the text calls attention to the need of an increase in blood donations, in what seems to add strength to the persuasive effect of the indirect request that is found (impersonally) in: "Blood donations also need to be increased". This is an instance of the NPS7 strategy, which, according to B\&L, expresses the speaker's concern that the hearer's wishes are not imposed.

The text ends with an off-record appeal conveyed by the metonymy "This action is in your hands". Although B\&L do not mention metonymy as a covered politeness strategy, cognitive approaches argue that this figure of speech, like the metaphor, is conceptual in nature (LAKOFF, 1987, p. 288). Based on this argument, we will include the metonymy as part of ORPS9, in B\&L categorization. Moreover, it is interesting to note that "metonymies based on body parts provide a good resource to understand human states, behavior and actions in terms of what is familiar and well-understood" (ALADAILEH; ABBADI, 2012, p. 73). Such resource has been used productively in communication in general and in particular by advertising. Therefore, in the utterance "This action is in your hands", the metonymy consists in using "hands" to refer to the person as a whole. In Brazilian Portuguese, to say (metonymically) that "an action X is in somebody's hand" means that action X depends on that person. This latter meaning is well accepted by convention in this language, and is therefore clear to native speakers. Indeed, B\&L (1987, p. 212) had already warned about this point when they observed that "many of the classic off-record strategies [...] are very often actually on record when used, because the clues to their interpretation [...] add up to only one really viable interpretation in the context".

The statistical data already given above are repeated on the left side of part 2 of the folder, along with the following utterances:

Essas conquistas só foram possíveis graças aos doadores de sangue [PPS2]. O que parece ser um simples gesto de solidariedade, na verdade, é uma ação que pode salvar milhares de pessoas em todo o país [PPS11] [PPS13]. Por isso, entre nessa campanha. E se você [PPS4] já é doador, continue doando sempre. O Brasil inteiro agradece a sua participação.

These achievements were only possible thanks to blood donors. What seems to be a simple act of solidarity is actually an action that can save thousands of people all over the country. So be a part of this campaign. If you are already a donor, keep donating. All of Brazil thanks your participation.

Alex Carvalho passou por uma cirurgia e precisou de uma transfusão de sangue.

Alex Carvalho went through surgery and needed a blood transfusion.

Right after, their use is reiterated, and statistical data are labeled by the nominalization "these achievements". Within the scope of textual linguistics, it has been considered that referencing consists in "construction and reconstruction of discourse objects" (KOCH; ELIAS, 2011b, p. 123). In this way, replacing the processes introduced in the three previous declarations (Organ transplants have increased 84\%; surgeries have increased $619 \%$; emergency treatments have increased $627 \%$ ) by the nominal phrase 
"these achievements" is evidence of reconstruction of those discursive objects. Such recategorization may work as a strategy aimed at keeping a positive face, especially of those readers who are already blood donators, as the utterance carries an implicit approval and acknowledgment of them [PPS2].

We believe that the consideration that blood donation "is an action that can save thousands of people all over the country" projects an optimistic image of the advertiser [PPS11], [ORPS5], while at the same time expressing a good reason for new donators to join the effort [PPS13], followed by the invitation: "So be a part of this campaign".

In the utterance "And if you already are a donor, keep donating", there is for the first time a direct reference to the reader by means of the pronoun in the second person você ("you"). As it has been already mentioned, in Brazilian Portuguese this pronoun is related to equality of power and with proximity [PPS4] among those involved in an interaction.

Finally, in "All of Brazil thanks your participation", we have again the use of strategies PPS11 (be optimistic) and ORPS5 (exaggerate the importance), since the anticipated thanks may project the advertiser confidence that those who are already donors will keep contributing. Because the expression "All of Brazil" has the meaning, through association, of "thousands of people all over the country", it appears to us be possible to assume that the positive face projected in the thanks would be that of the Brazilian population itself.

\section{CONCLUDING COMMENTS}

When it comes to texts that combine different semiosis, in which image and verbal signs come together, we cannot disregard one language in favor of the other. In the same way that verbal language offers many possibilities to produce a text, non-verbal signs are also organized according to social and discursive conditions. In other words, images are manipulated to obtain the desired effects: the omission or clarification of certain details when producing images is not random, but directly related to ideological implications, as explained by Kress and van Leeuwen (2006). This happens because the authors of the images are part of a cultural and social space, and so their values, beliefs, aspirations and frustrations permeate the way their compositions are planned.

Undeniably, the analysis of the advertising pieces presented in this study demonstrates a strong relationship of complementarity between verbal and non-verbal elements. In both texts, the way their arrangements were planned - plane and angle used in photography, the look of the portrayed participants - gives to the observer (the interactive participant) the feeling of intimacy with both the scene and the represented participant, prompting her or him to engage in the campaign. Working together, the nonverbal resources and verbal facework strategies, especially those focusing on the positive face wants, contribute to create an environment of closeness between those involved in the interactional circumstances. All of that becomes a persuasion strategy.

The prevalence of positive politeness strategies in our data corroborates the findings of Dias and Gusso (2015) and is similar to the results found by Pennock-Speck and del Saz-Rubio (2013) in their analysis of a corpus of television campaigns in Great Britain. 
These results suggest that the advertising agencies would be deliberately employing PPS's as "a kind of social accelerator" (B\&L, 1987, p. 103). Through their use, the advertiser shows his desire of, somehow, move closer to the audience (in the case of television advertisements) or to the reader (in the case of printed publicity such as folders and posters). In this way, the use of positive politeness strategies emphasizes the group identity and seeks to create an optimistic atmosphere that at the same time redresses the intrusion of the advertiser into the reader's freedom of action, making her or him feel more at ease.

Our analysis, by means of the tools offered from the Grammar of Visual Design, showed that, indeed, in the advertising community the manipulation of visual language is a resource used as a persuasion strategy, formulated with the intention of both seducing the reader and catching his or her attention, given that the textual genres of advertising have this purpose.

To conclude, we want to strengthen the argument that for the critical analysis of multisemiotic texts, it is essential to give due value to visual elements. Therefore, one cannot ignore that the description and interpretation of the compositional aspects of the image are worthy of the same attention given to the verbal elements.

\section{REFERENCES}

AL-ADAILEH, B. A.; ABBADI, R. The pragmatic implications of metonymical body-based idioms in Jordanian Arabic Argumentum. Debreceni Egyetemi Kiadó, v. 8, p. 73-91. 2012.

ATKIN, C. K.; RICE, R. E. Theory and Principles of Public Communication Campaigns. In: RICE, R. E.; ATKIN, C. K. (Eds.). Public Communication Campaigns. $4^{\text {th }}$ ed. Los Angeles: Sage Publications, 2013. p. 3-19.

BERNHARDT, J. M. Communication at the core of effective public health. American Journal of Public Health, v. 94, n. 12, p. 2051-2053, 2004.

BRANDÃO, E. P. Conceito de comunicação pública. In: DUARTE, J. (Org.). Comunicação pública: estado, mercado, sociedade e interesse público. 2. ed. São Paulo: Atlas, 2009. p. 1-33.

BRASIL, 2014. Ministério da Saúde lança nova campanha de doação de sangue. Informe técnico. Retrieved from: <http://portalsaude.saude.gov.br/index.php/cidadao/principal/agencia-saude/13355ministerio-da-saude-lanca-nova-campanha-de-doacao-de-sangue>. Access: 7 Jan. 2016.

BROWN, P.; LEVINSON, S. C. Politeness: Some Universals in Language Usage. Cambridge: Cambridge University Press, 1987 [1978].

DEL SAZ-RUBIO, M. M. La cortesía lingüística en el discurso publicitario. Valencia: Universitat de València, 2000.

Análisis pragmalingüístico de las estrategias de cortesía lingüística en la publicidad del siglo

XXI. In: PALACIOS, J.; SERRA, P. A. (Eds.). Pragmática: Comunicação Publicitária e Marketing. Covilhã: Livros LabCom, 2011. p. 5-26.

DIAS, L. S.; GUSSO, A. M. Análise multimodal das estratégias de polidez em campanhas de doação de sangue do Ministério da Saúde. In: WORKSHOP INTERNACIONAL DE PRAGMÁTICA, 2. Curitiba, PR. Anais... Curitiba: Universidade Federal do Paraná, 2015. p. 40-53. Retrieved from:

http://files.workshopinternacional.webnode.com/200000397-79cec7bc33/E-book\%20II\%20WIP.pdf. Access: 07 Jan. 2016.

DIONÍSIO, A. P. Gêneros multimodais e multiletramento. In: KARWOSKI, A. M.; GAYDECZKA, B; BRITO, K. S. (Org.). Gêneros textuais: reflexões e ensino. Palmas e União da Vitória: Kaygangue, 2005. p. 159-177.

EELEN, G. A Critique of Politeness Theories. Manchester: St. Jerome, 2001.

DIAS, Luzia Schalkoski; GUSSO, Angela Mari. “Do you need to know the person to donate?” Facework strategies in Brazilian blood donation campaigns: a multimodal analysis. Linguagem em (Dis)curso - LemD, Tubarão, SC, v. 16, n. 3, p. 401-419, set./dez. 2016. 
ESCRIBAÑO, A. La cortesía lingüística como recurso publicitario. Zer: Revista de estudios de comunicación, Bilbao, v. 20, 2006 (Universidad del País Basco).

FOLDER. Campanha Seja para quem for, seja doador. 2014. Retrieved from: http://portalarquivos.saude.gov.br/campanhas/2014/Doacao_de_Sangue/MS_DOACAO_DE_SANGUE_ FOLDER_A5.jpg. Access: 07 Jan. 2016.

GOFFMAN, E. Interactional Ritual: Essays on Face to Face Behaviour. New York: Garden City, 1967. JOHNSTONE, B. Perspectives on repetition. An introduction. Text, v. 7, n. 3, p. 205-214. 1987.

KARWOSKI, A. M. Estratégias de leitura de fôlderes. Estudos Lingüísticos XXXIV, p. 698-701, 2005.

KARWOSKI, A. M.; GAYDECZKA, B.; BRITO, K. S. (Org.). Gêneros textuais: reflexões e ensino. Palmas e União da Vitória, PR: Kaygangue, 2005.

KOCH, I. V.; ELIAS, V. M. Ler e escrever: estratégias de produção textual. 2. ed. São Paulo: Contexto, $2011 \mathrm{a}$.

Ler e compreender os sentidos do texto. 3. ed. São Paulo: Contexto, 2011b.

KRESS, G.; VAN LEEUWEN, T. Reading Images: The Grammar of Visual Design, $2^{\text {nd }}$ ed. London: Routledge, 2006.

LAKOFF, G. Women, Fire, and Dangerous Things. Chicago: University of Chicago Press, 1987.

MARCUSCHI, L. A. Gêneros textuais: configuração, dinamicidade e circulação. In: KARWOSKI, A. M.; GAYDECZKA, B.; BRITO, K. S. (Org.). Gêneros textuais: reflexões e ensino. Palmas e União da Vitória, PR: Kaygangue, 2005.

MATSUMOTO, Y. Reexamination of the universality of face: politeness phenomena in Japanese. Journal of Pragmatics, v. 12, n. 4, p. 403-426, 1988.

PALACIOS, A. da R. J.; SENA, J. L. de. Abordagens sobre sistema social de polidez, vínculos com a noção de face e estratégias discursivas da publicidade direcionada para idosos, no Brasil. In: FERREIRA, I.; GONÇALVES, G. (Orgs.). Retórica e Mediatização: As Indústrias da Persuasão. Covilhã: LabCom Books, 2010. p. 45-72.

PENNOCK-SPECK, B.; DEL SAZ-RUBIO, M. M. A multimodal analysis of facework strategies in a corpus of charity ads on British television. Journal of Pragmatics, v. 49, p. 38-56, 2013.

PISHGHADAM, R.; NAVARI, S. A Study into Politeness Strategies and Politeness Markers in Advertisements as Persuasive Tools. Mediterranean Journal of Social Sciences, v. 3, n. 2, p. 161-171, 2012.

PORTAL PLANALTO. Campanha do Ministério da Saúde estimula doação de sangue entre os jovens. 2013. Retrieved from: http://www2.planalto.gov.br/excluir-historico-nao-sera-migrado/campanha-doministerio-da-saude-estimula-doacao-de-sangue-entre-os-jovens. Access: 07 Jan. 2016.

POSTER. Campanha Seja para quem for, seja doador. 2013. Retrieved from: https://fenafal.files.wordpress.com/2013/06/cartaz_olivio_foto_nova.jpg._Access: 07 Jan. 2016. RABAÇA, C. A.; BARBOSA, G. Dicionário de Comunicação. Rio de Janeiro: Campus, 1995. RICE, R. E.; ATKIN, C. K. Public communication campaigns: Theoretical principles and practical applications. In: BRYANT, J.; Oliver, M. (Eds.). Media effects: Advances in theory and research. $3^{\text {rd }}$ ed. Hillsdale, NJ: Lawrence Erlbaum, p. 436-468. 2009.

SCOLLON, R.; LEVINE, P. Multimodal Discourse Analysis as the Confluence of Discourse and Technology. In: LEVINE, P.; SCOLLON, R. (eds.). Discourse and technology: multimodal discourse analysis. Washington, D.C: Georgetown University Press, 2004.

THOMPSON, J. B. A mídia e a modernidade: uma teoria social da mídia. Tradução de Wagner de Oliveira Brandão. 11. ed. Petrópolis: Vozes, 2009.

VAN LEEUWEN, T. Ten reasons why linguists should pay attention to visual communication. In: LEVINE, P.; SCOLLON, R. (Eds.). Discourse and technology: multimodal discourse analysis. Washington, D.C: Georgetown University Press, 2004.

WORLD HEALTH ORGANIZATION - WHO. Campaign essentials. World Blood Donor Day. 2014. Retrieved from: http://apps.who.int/iris/bitstream/10665/112768/1/WHO_World-Blood-Donoray_2014.1_eng.pdf?ua=1\&ua=1._Access: 07 Jan. 2016.

ZEMOR, P. La comunication publique. 3. ed. Paris: PUF, 2005.

DIAS, Luzia Schalkoski; GUSSO, Angela Mari. “Do you need to know the person to donate?” Facework strategies in Brazilian blood donation campaigns: a multimodal analysis. Linguagem em (Dis)curso - LemD, Tubarão, SC, v. 16, n. 3, p. 401-419, set./dez. 2016. 
Recebido em: 07/01/16. Aprovado em: 24/07/16.

Título: "Para doar sangue, você precisa conhecer a pessoa?" Estratégias de polidez em campanhas brasileiras de doação de sangue: uma análise multimodal

Autoras: Luzia Schalkoski Dias; Angela Mari Gusso

Resumo: Neste estudo, busca-se evidenciar o potencial analítico que a inter-relação entre a Teoria da Polidez (BROWN; LEVINSON, 1987) e a abordagem semiótica da Gramática do Design Visual (KRESS; VAN LEEUWEN, 2006) pode oferecer para a análise de estratégias de polidez usadas em peças publicitárias de comunicação pública. Realiza-se uma análise qualitativa de duas peças publicitárias de campanhas de doação de sangue promovidas pelo Ministério da Saúde brasileiro. Os gêneros textuais analisados, um pôster e um folder, caracterizam-se pela multimodalidade semiótica; assim, recursos verbais e não verbais são articulados para a produção dos significados sociais pretendidos. A análise evidenciou que, assim como as estratégias de polidez positiva são usadas pelos anunciantes para buscar uma aproximação com o público-alvo, a linguagem visual também é manipulada segundo determinados padrões, de forma a capturar a atenção dos interlocutores e seduzi-los. $O$ corpus sugere que as estruturas visuais reforçam as estratégias verbais utilizadas para intensificar a atmosfera de proximidade entre os envolvidos na situação de interação.

Palavras-chave: Multimodalidade. Estratégia de polidez. Publicidade. Doação de sangue.

Título: "Para donar sangre, ¿usted necesita conocer la persona?” Estrategias de cortesía en campañas brasileñas de donación de sangre: un análisis multimodal

Autoras: Luzia Schalkoski Dias; Angela Mari Gusso

Resumen: En este estudio se busca evidenciar el potencial analítico que la inter-relación entre la Teoría de la Cortesía (BROWN; LEVINSON, 1987) y el abordaje semiótica de la Gramática del Diseño Visual (KRESS; VAN LEEUWEN, 2006) puede ofrecer para el análisis de estrategias de cortesía usadas en piezas publicitarias de comunicación pública. Se realiza un análisis cualitativa de dos piezas publicitarias de campañas de donación de sangre promovidas por el Ministerio de la Salud brasileño. Los géneros textuales analizados, un póster y un fólder, se caracterizan por la multimodalidad semiótica. Así, recursos verbales y no verbales son articulados para la producción de los significados sociales pretendidos. El análisis he evidenciado que, así como las estrategias de cortesía positiva son usadas por ellos anunciantes para buscar una aproximación con o público-objetivo, el lenguaje visual también es manipulado segundo determinados estándares, de manera a capturar la atención de los interlocutores y seducirlos. El corpus sugiere que las estructuras visuales refuerzan las estrategias verbales utilizadas para intensificar la atmosfera de proximidad entre los involucrados en la situación de interacción.

Palabras-clave: Multimodalidad. Estrategia de cortesía. Publicidad. Donación de sangre.
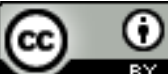

Este texto está licenciado com uma Licença Creative Commons Atribuição 4.0 Internacional.

DIAS, Luzia Schalkoski; GUSSO, Angela Mari. “Do you need to know the person to donate?” Facework strategies in Brazilian blood donation campaigns: a multimodal analysis. Linguagem em (Dis)curso - LemD, Tubarão, SC, v. 16, n. 3, p. 401-419, set./dez. 2016. 